\title{
Major Barriers to Manufacturing SMEs Growth and Survival: Evidence from Emerging Economy Pakistan
}

\author{
Sher Ali a , Hazrat Bilal ${ }^{\text {b }}$, Ashfaq Ahmad ${ }^{\text {c, Jawad Hussain }}{ }^{\text {d }}$ \\ ${ }^{a}$ PhD Scholar, College of Economics and Management, China Three Gorges University, 4430oo Yichang, \\ China \\ E-mail: Sherali9404@gmail.com \\ ${ }^{\mathrm{b}}$ Assistant Professor, Centre for Management and Commerce, University of swat, Pakistan \\ E.mail: hbilal@uswat.edu.pk \\ ${ }^{\mathrm{c}}$ Assistant Professor, Centre for Management and Commerce, University of swat, Pakistan \\ E.mail: ashfaqahmad79@outlook.com \\ d Associate Professor, Department of Commerce and Management Sciences, University of Malakand, \\ Pakistan \\ E.mail: jawadhussain79@gmail.com
}

\begin{tabular}{|c|c|}
\hline ARTICLE DETAILS & \multirow{11}{*}{$\begin{array}{l}\text { ABSTRACT } \\
\text { SMEs play a tremendous role in increased national economic } \\
\text { development and consider the backbone of the economy around the } \\
\text { world. It contributes a great share in the GDP of Pakistan and a huge } \\
\text { number of the workforce involved. However, despite such great } \\
\text { importance, the SMEs growth in Pakistan faces numerous challenges for } \\
\text { access to financial resources, market information, and procurement } \\
\text { contract. Hence the main aim behind this study is to investigate the } \\
\text { influence of these barriers on manufacturing SMEs' growth and survival. } \\
\text { A structured questionnaire was distributed among } 172 \text { managerial level } \\
\text { employees of manufacturing SMEs to explore the influence of financial } \\
\text { resources, market information, and procurement contract on the growth } \\
\text { of SMEs by incorporating the Structural Equation Model (SEM). The } \\
\text { study shows that the lack of access to financial resources, market } \\
\text { information, and procurement contract negatively influence the growth } \\
\text { and survival of SMEs. Therefore, it needs a certain action to eliminate } \\
\text { such barriers for SMEs' sustainable growth and survival. This study } \\
\text { suggestion will help to contribute to policymakers and industry players } \\
\text { to overcome such barriers. }\end{array}$} \\
\hline Histo & \\
\hline Accepted og Dec 2020 & \\
\hline & \\
\hline & \\
\hline Manufacturing SMEs, Financial & \\
\hline & \\
\hline & \\
\hline JEL & \\
\hline $\mathrm{O} 14, \mathrm{P} 43$ & \\
\hline DOI: 10.470 & \\
\hline
\end{tabular}

(C) 2020 The authors. Published by SPCRD Global Publishing. This is an open access article under the Creative Commons Attribution-

NonCommercial 4.0

Corresponding author's email address: hbilal@uswat.edu.pk

\section{Introduction}

SMEs has several definitions around the world and even numerous institutions in the same country have a unique definition (Cardoza et al., 2015). In the context of Pakistan SMEs distinct on the 


\section{Review of Economics and Development Studies, Vol. 6 (4) 2020, 845 - 856}

number of employees up to-250 or paid-up capital of Rs. 25 million (Khan, Qureshi, \& Abbas, 2010; Kureshi, Qureshi, \& Sajid, 2010). Although SMEs have limited resources and internal house-based knowledge (Brenes, Camacho, Ciravegna, \& Pichardo, 2016; Felzensztein, Ciravegna, Robson, \& Amorós, 2015; Viljamaa, 2011). In this era of globalization, national economies renovate into a single economy (Ali, Bilal, \& Ullah) hence for survival and growth SMEs need effectively deploy resources (Brouthers, Nakos, \& Dimitratos, 2015). Over the last decades, research on SMEs has gained a tremendous increase. Numerous scholars concentrated on various factors that influence SME growth (Audretsch, 2004; Constantinides, 2010; Wiklund, Patzelt, \& Shepherd, 2009). Although literature indicated that most of the SMEs thought out the world faces same problems in survival and growth like a) lace access to financial resources b) insufficient market information and c) procurement of contract (Cardoza, Fornes, Farber, Duarte, \& Gutierrez, 2016; Hollender, 2017; Zhou \& de Wit, 2009) In the case of the emerging economy, Pakistan SMEs constitute about $90 \%$ of overall enterprises and approximately 40\% share in GDP. SMEs have a great contribution to Pakistan's economic development and a large work-force involvement. But SMEs face abundant challenges for their survival and growth. Hence this study will focus on the major barriers to manufacturing SMEs growth in the context of Pakistan.

\section{Literature Review}

Manufacturing SMEs have been considering one of the most important sectors for the development of economies around the world (Halabí \& Lussier, 2014; Hessels \& Parker, 2013; Makhmadshoev, Ibeh, \& Crone, 2015; Oparaocha, 2015). Many scholars were cited that almost in many developed as well in developing countries of the world SMEs responsible for more than $60 \%$ of the economic growth (Alonso \& Bressan, 2015; Brouthers et al., 2015; Timm, 2012; Viljamaa, 2011). SMEs are limited house-base knowledge and resource-constrained (Prange \& Pinho, 2017)and have faced a lot of challenges for their growth and market survival. Several authors have carried out substantial research on numerous barriers that influence the growth of SMEs (Fillis, Johannson, \& Wagner, 2004). These scholars analyze the major barriers in contrast to developed as well from emerging economies(Buzavaite \& Korsakiene, 2019). The literature indicates that most of the barriers from the developed and emerging economy are similar to scholars cited earlier(Tschetschonig, 2012). Although the major barriers that SMEs faced for their growth are market information (Child \& Hsieh, 2014; Kmieciak \& Michna, 2018) and an unfavorable regulatory environment (Mogos et al., 2010) lack of access to financial resources(Lee, 2014; Virglerová, Homolka, Smrčka, Lazányi, \& Klieštik, 2017) procurement contract and unfavorable regulatory environment(Williams \& Horodnic, 2016). In the case of the emerging economy, many scholars recognized lack of access to financial resources, lack of access to market information, and procurement of contracts are the major barriers to the growth and survival of SMEs (Huett, Baum, Schwens, \& Kabst, 2014). In fact, literature clarifying that these major barriers hider the capability of SMEs growth and survival. (Cardoza et al., 2016) cited that besides the financial barriers market information and procurement of contracts influence the SMEs' growth.

Consequently, it needs to design and implement the strategies, policies, and programs that turn enhance sustainable SMEs' growth, survival, and competitiveness in developed as well in emerging economics(Cardoza et al., 2016). It has been identified that numerous countries have developed and implements varied policies and programs to ensure the growth and survival of SMEs(Cenamor, Parida, \& Wincent, 2019; Taschner, 2012) and to overcome the major barriers and challenges. The causes are likely to originate from the numerous barriers which persist the SMEs' growth (Halabí \& Lussier, 2014) the major barriers are the financial resources access, lack of market information, internal limited house-base knowledge, and procurement of contract (Bianchi \& Wickramasekera, 2016). Hence this paper will empirically explore the nature of the major barriers such as a) lack of access to financial 


\section{Review of Economics and Development Studies, Vol. 6 (4) 2020, 845 - 856}

resources b) lack of enough market information and c) procurement contract. In the context of this research, the SMEs' growth was measured by the increase of sales and innovation in existence and new products(Mathews, Bianchi, Perks, Healy, \& Wickramasekera, 2016). SMEs' growth has a positive influence on short as well on long-term sustainability (Coad et al., 2012). Although, the SMEs growth can be attained by the innovation of new product or expanding into the new geographic market at local and/or abroad (Eggers, O’Dwyer, Kraus, Vallaster, \& Güldenberg, 2013)also the introduction of new services. Besides that, the growth of SMEs can also be indicated both in terms of employment or sales of goods and providing services(Hessels \& Parker, 2013). SMEs' growth can ensure the product quality, increase the market share, competitive edge over others, long-run sustainable benefit, and increase in socioeconomic and poverty alleviation (Javalgi \& Todd, 2011). Initially, the growth rate of SMEs is faster because it is uncertain about their cost and less market efficient scale and managerial cost. However, SMEs are less flexible to the adaptability of new market trends and technology for innovation, growth, and market survival. This implies that to overcome such difficulties SMEs need an energetic enterprise policy mechanism to get out of such with easier access to financial resources, market information, and procurement contract. It argues, that to ensure the SMEs' growth and survival in industrial policy the SMEs should be a central plank of the private and government sector (Kolodko, 200o)But in an emerging economy, especially in Pakistan the growth and survival of SMEs are not satisfactory. While manufacturing SMEs has a huge portion in the national GDP of Pakistan and mitigation a remarkable number of unemployment.

\section{Research Model and Hypothesis Development}

This study will determine the influence of major barriers on SMEs' growth and survival like a) financial barriers b) market information barrier c) procurement of contract barriers. Pakistan is a densely populated country of about 212.2 million (2018) and SMEs have 90\% of overall enterprises and approximately $40 \%$ share in GDP. Due to the financial crisis and high unemployment rate in manufacturing SMEs, survival and growth are very important to overcome such a worse economic situation. But the growth and survival of SMEs face major barriers of financial resources, market information, and procurement of contracts. Therefore, this study will empirically identify the influence of these barriers on SMEs growth in the context of Pakistan.

H1: Lack of access to financial resources negatively influence the SMEs growth and survival.

Lack access of financial resources is one of the major barriers to SMEs growth and survival. It has been cited by many scholars from developed and emerging economies that financial barriers are the most significant obstacle to SMEs' growth and survival(Arora \& Ceccagnoli, 2006; Zhu, Wittmann, \& Peng, 2012). Financial access is the most controversial issue in the SME sector. Most of the studies identified that access to financial resources is a major barrier for new as well for already functional SMEs(Krasniqi, 2007).The lack of financial resources especially in the case of emerging economies is a significant barrier which many constraints the growth and survival of SMEs(Lee, Sameen, \& Cowling, 2015). Many studies identify that after globalization, worldwide financial crises and economic disabilities have increased the importance of financial resources for their growth and survival of SMEs(Daskalakis, Jarvis, \& Schizas, 2013). Access to financial resources significantly increases the internal and external capability of SMEs, like invest in production units, R\&D initiatives, entrance to the local and international market, and increase in house-based knowledge (Lee \& Drever, 2014). Financial barriers are the lack of financial resources like credit constraints, subsidies, and loans, lack of external debts, and equity capital to SMEs' growth(Coad \& Tamvada, 2012; Huett et al., 2014). The most substantial reason for SMEs access to financial resources includes the high-interest rate, information asymmetry, poor and complex application process government and private sectors mechanisms, high 


\section{Review of Economics and Development Studies, Vol. 6 (4) 2020, 845 - 856}

fee, and poor performance of SMEs (Doh \& Kim, 2014). Furthermore see (Fredriksson, Maresch, \& Moro, 2017; Hanedar \& Hanedar, 2016).

H2: Lack of access to procurement or supplier development negatively influence the SMEs growth and survival.

Lack of access to procurement or supplier development is a significant barrier(Cardoza, Fornes, Farber, Gonzalez Duarte, \& Ruiz-Gutierrez, 2015) and it negatively influences the growth and survival of SMEs in emerging as well in developed economies (Cardoza et al., 2016). The procurement contract provides a favorable and potential competitive edge in national as well beyond the boundaries (Bianchi \& Saleh, 2020)The procurement of contract significantly promote commercial relationship among suppliers, promote the sale, employment, and their ability to growth and survival(Sibiya \& Kele, 2019b).The lack of procurement contract in SMEs growth and survival is debatable and gains the marvelous attention of scholars since research indicates mixed evidence(Blattman, Dercon, \& Franklin, 2019; Sibiya \& Kele, 2019b). Supplier development or procurement contracts influence more positively the SMEs performance is a value chain process. The access to procurement contract benefits SMEs in terms of access to resources such as human skills, technology access, competencies gain, and reduce the risk and cost of doing business. Recently research highlighted the significance of the procurement contract and identified is a major barrier to the growth and survival of SMEs' expansion. Hence it needs for SMEs to create flexibility in their structure and adopted public/private procurement contracts in their policies and practices for sustainable growth and market survival(Bartlett \& Bukvič, 2002). Therefore, the government and private sector would be required to design policies and regulations, where different players encourage to take initiatives for the development of SMEs procurement contracts. Consequently, such initiatives will make SMEs capable of sustainable growth and overcome procurement barriers(Sibiya \& Kele, 2019a).

H3: Lack of access to market information negatively influence the SMEs growth and survival.

Lack of access to market information negatively influences SMEs' growth and survival (Hamisi, 2011; Huett et al., 2014; Siringoringo, Prihandoko, \& Kowanda, 2009; Tambunan, 2009). Market information reduces the risks and can significantly improve the capabilities of SMEs to cope with challenges(Joensuu-Salo, Sorama, Viljamaa, \& Varamäki, 2018; Sibiya \& Kele, 2019a). Many scholars are cited that the lack of information is a major barrier to SMEs' growth and survival(Irjayanti \& Azis, 2012; Sibiya \& Kele, 2019a). Weak or lack of market information decreased the chance of SMEs to exploit the growth and survival opportunities more favorable (Al-Mubarak, 2016). SMEs have a constrained housebase knowledge and limited resources thus the lack of market information is a major barrier to SMEs' growth and survival. The lack of access to market information negatively impacts knowledge limitation about the business in local and well beyond the boundaries and caused poor product standard and quality. Several scholars identify the lack of market information as one of the major barriers to SMEs' growth and survival(Child \& Hsieh, 2014) and from social and business networks (Mogos Descotes \& Walliser, 2013). But the market information depends on the quality of the information source. However, SMEs need domestic and foreign alliances, formal and informal networks, and cooperation with export intermediaries to overwhelmed the barriers of market information (Cardoza \& Fornes, 2011; Jin \& Jung, 2016)

\section{Research Methodology}

In these study quantities method has been used and data were collected through a structured questionnaire from 172 managerial level employees of the manufacturing SMEs from the Malakand 
Review of Economics and Development Studies, Vol. 6 (4) 2020, 845 - 856

region of KPK, Pakistan by random sampling method. The data was incorporated by the Structural equation model (SEM). The independent variable of the study is consisting of three major barriers a). lack access to financial barriers b). lack access to market information c). lack access to procurement contract while on other hand dependent variable is the SMEs growth and survival. Bartlett, Kotrilk and Higgins (2001) formula was used to obtain the required sample size of the study and the sample size was 172 managerial level employees of the manufacturing SMEs.

\section{Results and Analysis of the study}

\subsection{Demographic picture of the respondent}

The table 1 below shows the demographic characteristics of the respondent by age, family income and education status

Table: 1 Demographic Characteristic of the Respondent

\begin{tabular}{|l|l|l|}
\hline Age & Frequency & Percent \\
\hline $18-30$ & 40 & $23 \cdot 3 \%$ \\
\hline $31-40$ & 55 & $32.0 \%$ \\
\hline $41-50$ & 47 & $27.3 \%$ \\
\hline$>50$ & 30 & $17.4 \%$ \\
\hline Total & $\mathbf{1 7 2}$ & $\mathbf{1 0 0 . 0} \%$ \\
\hline Family income & & \\
\hline 3000oandless & 1 & $.6 \%$ \\
\hline $31000-60000$ & 21 & $12.2 \%$ \\
\hline $61000-80000$ & 62 & $36.0 \%$ \\
\hline$>91000$ & 88 & $51.2 \%$ \\
\hline Total & $\mathbf{1 7 2}$ & $\mathbf{1 0 0 . 0} \%$ \\
\hline Education & & \\
\hline Illiterate & 3 & $1.7 \%$ \\
\hline primary & 37 & $21.5 \%$ \\
\hline secondary & 93 & $54.1 \%$ \\
\hline Diploma or higher & 39 & $\mathbf{2 2 . 7} \%$ \\
\hline Total & $\mathbf{1 7 2}$ & $\mathbf{1 0 0 . 0} \%$ \\
\hline
\end{tabular}

The evidence from below table 2 shows that there is strong negative relationship between the growth and survival of SMEs and major barriers (lack access to financial resources, lack access to market information, lack access to procurement contract). The proposed hypothesis of the study was that there is a negative relationship between SMEs financial barriers $\left(r=0.294^{* *}\right)$ at significant level of $\mathrm{p}<0.05$, thus support the first hypothesis of the study. The negative relationship between market information $\left(r=0.355^{* *}\right)$ and SMEs growth is significant $(\mathrm{p}<0.05)$ which support the second hypothesis of the study. The result of the study also supports the third hypothesis that procurement contract $\left(.404^{* *}\right)$ negatively and significantly affect the growth and survival of SMEs 
Review of Economics and Development Studies, Vol. 6 (4) 2020, 845 - 856

Table: 2 Correlations

\begin{tabular}{|l|l|l|l|l|}
\hline & Growth & Financial & Market & Procurement \\
\hline Growth and Survival & 1 & & &. \\
\hline Financial Barriers & $.294^{* *}$ & 1 & & \\
\hline Market information Barriers & $.355^{* *}$ & $.556^{* *}$ & 1 & \\
\hline Procurement contract Barriers & $.404^{* *}$ & $.674^{* *}$ & $.692^{* *}$ & 1 \\
\hline$* *$ Correlation is significant at the o.o1 level (2-tailed). & \\
\hline
\end{tabular}

The below table: 3 shows the variation characteristic between the lack of financial resources on the SMEs growth and survival. The $\mathrm{R}$ square for the give relation between lack of financial resources and SMEs growth and survival is .086 which mean 8.6\% variation in SMEs growth and survival occur due to lack of financial resources ( $\mathrm{p}<0.001$ with $\mathrm{F}=16.043$ ). Hence support the first hypothesis of the study that lack access of financial resources is negatively association with firm growth and survival.

Table: 3 Model Summary

\begin{tabular}{|l|l|l|l|l|l|l|l|l|l|}
\hline Model & $\mathrm{R}$ & $\mathrm{R}$ & Adjusted & Std. & \multicolumn{4}{l|}{ Change Statistics } \\
\cline { 4 - 9 } & & Square & R Square & $\begin{array}{l}\text { Error of } \\
\text { the } \\
\text { Estimate }\end{array}$ & $\begin{array}{l}\mathrm{R} \\
\text { Square } \\
\text { Change }\end{array}$ & $\begin{array}{l}\mathrm{F} \\
\text { Change }\end{array}$ & $\mathrm{df1}$ & $\mathrm{df2}$ & $\begin{array}{l}\text { Sig. } \\
\text { Change }\end{array}$ \\
\hline 1 & $.294^{\mathrm{a}}$ & .086 & .081 & .84947 & .086 & 16.043 & 1 & 170 & .000 \\
\hline
\end{tabular}

Below table 4 explore the strength of the negative relationships revealed by the value of slope and intercept for SMEs growth and survival. The constant value in table 3 for the given relationship is 2.037 and a slop of 0.502 regression line shows that one-unit change in lack of financial barriers can significantly predict 0.502 units change in SMEs growth and survival

Table 4: Coefficients ${ }^{\mathrm{a}}$

\begin{tabular}{|l|l|l|l|l|l|l|}
\hline \multicolumn{2}{|l|}{ Model } & \multicolumn{2}{l|}{ Unstandardized Coefficients } & $\begin{array}{l}\text { Standardized } \\
\text { Coefficients }\end{array}$ & \multirow{2}{*}{ Sig. } \\
\cline { 3 - 7 } \multicolumn{2}{|l|}{} & B & Std. Error & Beta & \\
\hline \multirow{2}{*}{1} & (Constant) & 2.037 & .453 & & 4.495 & .000 \\
\cline { 2 - 6 } & $\begin{array}{l}\text { Financial } \\
\text { barriers }\end{array}$ & .502 & .125 & .294 & 4.005 & .000 \\
\hline \multicolumn{2}{|l|}{ a. Dependent Variable: growth } & & & \\
\hline
\end{tabular}

The table 5 explores the variation characteristic between the lack of market information on the SMEs growth and survival. The $\mathrm{R}$ square value for the relationship between lack access to market information SMEs growth and survival is 0.126 which mean $12.6 \%$ of variation in SMEs growth and survival occur due to lack of market information ( $\mathrm{p}<0.001$ with $\mathrm{F}=24.5564)$. Thus, support the second hypothesis of the study that lack access to market information resource is negatively associate with the growth and market survival. 
Review of Economics and Development Studies, Vol. 6 (4) 2020, 845 - 856

Table: 5 Model Summary

\begin{tabular}{|c|c|c|c|c|c|c|c|c|c|}
\hline \multirow[t]{2}{*}{ Model } & \multirow[t]{2}{*}{$\mathrm{R}$} & \multirow{2}{*}{$\begin{array}{l}\mathrm{R} \\
\text { Square }\end{array}$} & \multirow{2}{*}{$\begin{array}{l}\text { Adjusted } \\
\text { R Square }\end{array}$} & \multirow{2}{*}{$\begin{array}{l}\text { Std. } \\
\text { Error of } \\
\text { the } \\
\text { Estimate }\end{array}$} & \multicolumn{5}{|c|}{ Change Statistics } \\
\hline & & & & & $\begin{array}{l}\text { R } \\
\text { Square } \\
\text { Change }\end{array}$ & $\begin{array}{l}\mathrm{F} \\
\text { Change }\end{array}$ & df1 & df2 & $\begin{array}{l}\text { Sig. F } \\
\text { Change }\end{array}$ \\
\hline 1 & $.355^{\mathrm{a}}$ & .126 & .121 & .83066 & .126 & 24.564 & 1 & 170 & .000 \\
\hline
\end{tabular}

The table 6 below shows the strength of the negative relation revealed by the value of slope and intercept for the growth and survival of SMEs. In table 5 the constant value of give relationships is 2.037 and slop of 0.481 on regression line which indicate that one unite change in lack access of market information significant predict 0.481 unite change in the growth and survival of SMEs.

Table: 6 Coefficients ${ }^{\mathrm{a}}$

\begin{tabular}{|l|l|l|l|l|l|l|}
\hline \multicolumn{2}{|l|}{ Model } & \multicolumn{2}{|l|}{ Unstandardized Coefficients } & $\begin{array}{l}\text { Standardized } \\
\text { Coefficients }\end{array}$ & \multirow{2}{*}{ Sig. } \\
\cline { 3 - 7 } \multicolumn{2}{|c|}{1} & B & Std. Error & Beta & & \\
\hline \multirow{2}{*}{1} & (Constant) & 2.073 & .361 & & 5.747 & .000 \\
\cline { 2 - 6 } & $\begin{array}{l}\text { Market } \\
\text { information }\end{array}$ & .481 & .097 & .355 & 4.956 & .000 \\
\hline
\end{tabular}

a. Dependent Variable: growth

Table 7 below shows the variation characteristic between the lack access to procurement contract on the SMEs growth and survival. The R square value for the given relationships between lack access to procurement contract and SMEs growth and survival is 0.163 which mean $16.3 \%$ of variation in SMEs growth and survival occur due to the lack access of procurement contract $(\mathrm{p}<0.001$ with $\mathrm{F}=$ 33.170). Therefore, support the third hypothesis of the study that lack access to procurement contract negatively influences the growth and survival of SMEs.

Table: 7 Model Summary

\begin{tabular}{|c|c|c|c|c|c|c|c|c|c|}
\hline \multirow[t]{2}{*}{ Model } & \multirow[t]{2}{*}{$\mathrm{R}$} & \multirow{2}{*}{$\begin{array}{l}\mathrm{R} \\
\text { Square }\end{array}$} & \multirow{2}{*}{$\begin{array}{l}\text { Adjusted } \\
\mathrm{R} \\
\text { Square }\end{array}$} & \multirow{2}{*}{$\begin{array}{l}\text { Std. } \\
\text { Error of } \\
\text { the } \\
\text { Estimate }\end{array}$} & \multicolumn{5}{|c|}{ Change Statistics } \\
\hline & & & & & $\begin{array}{l}\text { R } \\
\text { Square } \\
\text { Change }\end{array}$ & $\begin{array}{l}\mathrm{F} \\
\text { Change }\end{array}$ & df1 & df2 & $\begin{array}{l}\text { Sig. F } \\
\text { Change }\end{array}$ \\
\hline 1 & $.404^{\mathrm{a}}$ & .163 & .158 & .81287 & .163 & 33.170 & 1 & 170 & .000 \\
\hline
\end{tabular}

The below table 8 explore the strength of the negative relationships revealed by the value of slop and intercept for the growth and survival of SMEs. In table 7 the constant value of the relationship is 2.073 and the slop of 0.48 on regression line which shows that one unite change in lack access to procurement contract significant predict 0.481 unite change in the growth and survival of SMEs 
Review of Economics and Development Studies, Vol. 6 (4) 2020, 845 - 856

Table: 8 Coefficients ${ }^{\mathrm{a}}$

\begin{tabular}{|c|c|c|c|c|c|c|}
\hline \multirow{2}{*}{\multicolumn{2}{|c|}{ Model }} & \multicolumn{2}{|c|}{$\begin{array}{l}\text { Unstandardized } \\
\text { Coefficients }\end{array}$} & \multirow{2}{*}{$\begin{array}{l}\text { Standardized } \\
\text { Coefficients } \\
\text { Beta } \\
\end{array}$} & \multirow[t]{2}{*}{$\mathrm{t}$} & \multirow[t]{2}{*}{ Sig. } \\
\hline & & $\mathrm{B}$ & Std. Error & & & \\
\hline \multirow[t]{2}{*}{1} & (Constant) & 2.073 & .361 & & 5.747 & .000 \\
\hline & $\begin{array}{l}\text { Market } \\
\text { information }\end{array}$ & .481 & .097 & .355 & 4.956 & .000 \\
\hline
\end{tabular}

\section{Discussion and Conclusion}

The current study was carried to determine the influence of major barriers a) lack access to financial resources b) lack access to market information and c) lack access to procurement contracts on the growth of SMEs in the context of the emerging economy of Pakistan. The results of the analysis suggest that SMEs in Pakistan are still facing challenges for their growth and survival regarding the lack of financial resources, lack of access to market information, and procurement contracts. As from the previous finding of the researcher from developed as well developing economies the lack access to financial resources, lack of market information and lack access to procurement contract negatively influence the SMEs growth and survival Acs, Carlsson, \&Karlsson, 1999; OECD, 2008; Arora, 2009 Zhou, and Wit, 2009; Arráiz et al., 2012; Cardoza et al., 2015; Tambunan 2009; Siringoringo et al., 2009; Hamisi., 2011; Huett et al., 2014). The result also identified that in the context of the emerging economy of Pakistan for manufacturing SMEs is critical to growth and survival with these barriers. Hence, given these fact government need to design and implement policies and framework for the growth and survival of SMEs. Its need to facilitate and ensure the SMEs access to market information sufficient financial resources and procurement of contract with governmental organizations and as well as a private organization. Furthermore, the government can establish a favorable environment with market players of all necessary legislation which encouraged SMEs' growth and survival. The result indicates that lack of access to financial resources, lack of procurement contract, and lack of market information are the most significant barriers in the context of the emerging economy of Pakistan. therefore, it needs to do more for SMEs to make it easier and decreased the high collateral requirements, high-interest rate of return, high banks charges, bureaucracy ignorance of proposal, and a huge and short period of financial installment return. Furthermore, the lack of market information and procurement of contract constraint the SMEs growth and survival because such barriers increase the cost of production, failure of customer retain, prices of goods and material price, management skill; process; limitation of sales; and raw material risk and market uncertainty of product lunch and difficult to manage prediction for future business in local as well beyond the boundaries. Hence it needs to develop efficient assistance and cooperation between numerous stakeholders like business communities, promotional organizations, and private and government sectors to ensure the growth and survival of SMEs.

\section{References}

Al-Mubarak, M. M. (2016). Challenges of going global for SMES. International Journal of Innovation and Knowledge Management in the Middle East and North Africa, 5(1).

Ali, S., Bilal, H., \& Ullah, F. The Role of Cooperation Activities on Firm Perceived Performance. Evidence from Small and Medium Size Enterprises.

Alonso, A. D., \& Bressan, A. (2015). Resilience in the context of Italian micro and small wineries: an empirical study. International Journal of Wine Business Research.

Arora, A., \& Ceccagnoli, M. (2006). Patent protection, complementary assets, and firms' incentives for technology licensing. Management science, 52(2), 293-308. 
Review of Economics and Development Studies, Vol. 6 (4) 2020, 845 - 856

Audretsch, D. B. (2004). Sustaining innovation and growth: Public policy support for entrepreneurship. Industry and innovation, 11(3), 167-191.

Bartlett, W., \& Bukvič, V. (2002). What Are the Main Barriers to Small Business Growth in Southeast Europe? Small Enterprise Development in South-East Europe (pp. 17-37): Springer.

Bianchi, C., \& Saleh, M. A. (2020). Investigating SME importer-foreign supplier relationship trust and commitment. Journal of Business Research.

Bianchi, C., \& Wickramasekera, R. (2016). Antecedents of SME export intensity in a Latin American Market. Journal of Business Research, 69(10), 4368-4376.

Blattman, C., Dercon, S., \& Franklin, S. (2019). Impacts of industrial and entrepreneurial jobs on youth: 5-year experimental evidence on factory job offers and cash grants in Ethiopia: National Bureau of Economic Research.

Brenes, E. R., Camacho, A. R., Ciravegna, L., \& Pichardo, C. A. (2016). Strategy and innovation in emerging economies after the end of the commodity boom-Insights from Latin America. Journal of Business Research, 69(10), 4363-4367.

Brouthers, K. D., Nakos, G., \& Dimitratos, P. (2015). SME entrepreneurial orientation, international performance, and the moderating role of strategic alliances. Entrepreneurship theory and practice, 39(5), 1161-1187.

Buzavaite, M., \& Korsakiene, R. (2019). Human capital and the internationalisation of SMEs: A systemic literature review. Entrepreneurial Business and Economics Review, 7(3), 125-142.

Cardoza, G., \& Fornes, G. (2011). The internationalisation of SMEs from China: The case of Ningxia Hui autonomous region. Asia Pacific Journal of Management, 28(4), 737-759.

Cardoza, G., Fornes, G., Farber, V., Duarte, R. G., \& Gutierrez, J. R. (2016). Barriers and public policies affecting the international expansion of Latin American SMEs: Evidence from Brazil, Colombia, and Peru. Journal of Business Research, 69(6), 2030-2039.

Cardoza, G., Fornes, G., Farber, V., Gonzalez Duarte, R., \& Ruiz-Gutierrez, J. (2015). BARRIERS AND PUBLIC POLICIES AFFECTING THE INTERNATIONAL EXPANSION OF LATIN AMERICAN SMEs. Paper presented at the Academy of Management Proceedings.

Cenamor, J., Parida, V., \& Wincent, J. (2019). How entrepreneurial SMEs compete through digital platforms: The roles of digital platform capability, network capability and ambidexterity. Journal of Business Research, 100, 196-206.

Child, J., \& Hsieh, L. H. (2014). Decision mode, information and network attachment in the internationalization of SMEs: A configurational and contingency analysis. Journal of World Business, 49(4), 598-610.

Coad, A., \& Tamvada, J. P. (2012). Firm growth and barriers to growth among small firms in India. Small Business Economics, 39(2), 383-400.

Constantinides, E. (2010). Connecting small and medium enterprises to the new consumer: The Web 2.0 as marketing tool Global perspectives on small and medium enterprises and strategic information systems: International approaches (pp. 1-21): IGI Global.

Daskalakis, N., Jarvis, R., \& Schizas, E. (2013). Financing practices and preferences for micro and small firms. Journal of Small Business and Enterprise Development.

Doh, S., \& Kim, B. (2014). Government support for SME innovations in the regional industries: The case of government financial support program in South Korea. Research policy, 43(9), 1557-1569.

Eggers, F., O’Dwyer, M., Kraus, S., Vallaster, C., \& Güldenberg, S. (2013). The impact of brand authenticity on brand trust and SME growth: A CEO perspective. Journal of World Business, 48(3), 340-348.

Felzensztein, C., Ciravegna, L., Robson, P., \& Amorós, J. E. (2015). Networks, entrepreneurial 


\section{Review of Economics and Development Studies, Vol. 6 (4) 2020, 845 - 856}

orientation, and internationalization scope: evidence from Chilean small and medium enterprises. Journal of Small Business Management, 53(sup1), 145-16o.

Fillis, I., Johannson, U., \& Wagner, B. (2004). Factors impacting on e-business adoption and development in the smaller firm. International Journal of Entrepreneurial Behavior \& Research.

Fredriksson, A., Maresch, D., \& Moro, A. (2017). Much ado about nothing? Interest and noninterest products and services: Their impact on small banks' margins. Cogent Economics \& Finance, 5(1), 1339771.

Halabí, C. E., \& Lussier, R. N. (2014). A model for predicting small firm performance. Journal of Small Business and Enterprise Development.

Hamisi, S. (2011). Challenges and opportunities of Tanzanian SMEs in adapting supply chain management. African Journal of Business Management, 5(4), 1266-1276.

Hanedar, E. Y., \& Hanedar, A. Ö. (2016). Before and after the Crisis: A Look at the SMEs in Emerging Economies Risk Management in Emerging Markets: Emerald Group Publishing Limited.

Hessels, J., \& Parker, S. C. (2013). Constraints, internationalization and growth: A cross-country analysis of European SMEs. Journal of World Business, 48(1), 137-148.

Hollender, L. (2017). Internationalization Processes of SMEs: Foreign Market Entry Mode Choice, Experiential Learning, and Host-Country Selection. Universitäts-und Landesbibliothek der Heinrich-Heine-Universität Düsseldorf.

Huett, P., Baum, M., Schwens, C., \& Kabst, R. (2014). Foreign direct investment location choice of small-and medium-sized enterprises: The risk of value erosion of firm-specific resources. International Business Review, 23(5), 952-965.

Irjayanti, M., \& Azis, A. M. (2012). Barrier factors and potential solutions for Indonesian SMEs. Procedia economics and finance, 4, 3-12.

Javalgi, R. R. G., \& Todd, P. R. (2011). Entrepreneurial orientation, management commitment, and human capital: The internationalization of SMEs in India. Journal of Business Research, 64(9), 1004-1010.

Jin, B., \& Jung, S. (2016). Toward a deeper understanding of the roles of personal and business networks and market knowledge in SMEs' international performance. Journal of Small Business and Enterprise Development.

Joensuu-Salo, S., Sorama, K., Viljamaa, A., \& Varamäki, E. (2018). Firm performance among internationalized SMEs: The interplay of market orientation, marketing capability and digitalization. Administrative sciences, 8(3), 31.

Khan, M. I., Qureshi, M. A., \& Abbas, Q. (2010). Agile methodology in software development (SMEs) of Pakistan software industry for successful software projects (CMM framework). Paper presented at the 2010 International Conference on Educational and Network Technology.

Kmieciak, R., \& Michna, A. (2018). Knowledge management orientation, innovativeness, and competitive intensity: evidence from Polish SMEs. Knowledge Management Research \& Practice, 16(4), 559-572.

Kolodko, G. W. (2000). Transition to a market and entrepreneurship: the systemic factors and policy options 3 . Communist and Post-Communist Studies, 33(2), 271-293.

Krasniqi, B. A. (2007). Barriers to entrepreneurship and SME growth in transition: the case of Kosova. Journal of Developmental Entrepreneurship, 12(01), 71-94.

Kureshi, N., Qureshi, F., \& Sajid, A. (2010). Current health of quality management practices in service sector SME. The TQM Journal.

Lee, N. (2014). What holds back high-growth firms? Evidence from UK SMEs. Small Business 


\section{Review of Economics and Development Studies, Vol. 6 (4) 2020, 845 - 856}

Economics, 43(1), 183-195.

Lee, N., \& Drever, E. (2014). Do SMEs in deprived areas find it harder to access finance? Evidence from the UK Small Business Survey. Entrepreneurship \& Regional Development, 26(3-4), 337-356.

Lee, N., Sameen, H., \& Cowling, M. (2015). Access to finance for innovative SMEs since the financial crisis. Research policy, 44(2), 370-380.

Makhmadshoev, D., Ibeh, K., \& Crone, M. (2015). Institutional influences on SME exporters under divergent transition paths: Comparative insights from Tajikistan and Kyrgyzstan. International Business Review, 24(6), 1025-1038.

Mathews, S., Bianchi, C., Perks, K. J., Healy, M., \& Wickramasekera, R. (2016). Internet marketing capabilities and international market growth. International Business Review, 25(4), 820830.

Mogos Descotes, R., \& Walliser, B. (2013). Foreign market-related knowledge absorption and the international financial performance of SMEs. Management international/International Management/Gestiòn Internacional, 17(4), 178-193.

Oparaocha, G. O. (2015). SMEs and international entrepreneurship: An institutional network perspective. International Business Review, 24(5), 861-873.

Prange, C., \& Pinho, J. C. (2017). How personal and organizational drivers impact on SME international performance: The mediating role of organizational innovation. International Business Review, 26(6), 1114-1123.

Sibiya, V., \& Kele, T. (2019a). BARRIERS AND PUBLIC POLICIES IMPEDING SMES'INTERNATIONAL MARKET EXPANSION: A SOUTH AFRICAN PERSPECTIVE. International Journal of Entrepreneurship, 23(1), 1-19.

Sibiya, V., \& Kele, T. (2019b). Barriers and public policies impeding SMEs' international market expansion.

Siringoringo, H., Prihandoko, D., \& Kowanda, A. (2009). Problems faced by small and medium business in exporting products. Delhi Business Review, 10(2), 49-56.

Tambunan, T. T. H. (2009). SMEs in Asian developing countries: Springer.

Taschner, A. (2012). Umsetzungsoptionen eines KMU-spezifischen Kennzahlen-Managements. ZfKE-Zeitschrift für KMU und Entrepreneurship, 6o(2), 111-135.

Timm, S. (2012). How the state and private sector can partner to boost support to SMEs: Lessons from Chile \& Malaysia. Pretoria-Report for Department of Trade and Industry (South Africa) and Trade and Industrial Policy Strategies.

Tschetschonig, K. (2012). How SMEs protect critical knowledge in joint innovation activities with external partners: GRIN Verlag.

Viljamaa, A. (2011). Exploring small manufacturing firms' process of accessing external expertise. International small business journal, 29(5), 472-488.

Virglerová, Z., Homolka, L., Smrčka, L., Lazányi, K., \& Klieštik, T. (2017). Key determinants of the quality of business environment of SMEs in the Czech Republic. E a M Ekonomie a Management.

Wiklund, J., Patzelt, H., \& Shepherd, D. A. (2009). Building an integrative model of small business growth. Small Business Economics, 32(4), 351-374.

Williams, C. C., \& Horodnic, I. A. (2016). Cross-country variations in the participation of small businesses in the informal economy. Journal of Small Business and Enterprise Development.

Zhou, H., \& de Wit, G. (2009). Determinants and dimensions of firm growth., SCALES-Scientific AnaLysis of Entrepreneurship and SMEs,(February).

Zhu, Y., Wittmann, X., \& Peng, M. W. (2012). Institution-based barriers to innovation in SMEs in 
China. Asia Pacific Journal of Management, 29(4), 1131-1142. 